\title{
Social Management and ICTs: Enhancing Democratic Direct Participation
}

\author{
Flávio Ayres Marinho*1, Helga Midori Iwamoto² and Airton Cardoso Cançado ${ }^{3}$ \\ ${ }^{1}$ Doctorate student, Federal University of Tocantins (UFT), Brazil \\ ${ }^{2}$ Doctor in Administration, Federal University of Tocantins (UFT), Brazil \\ *Corresponding author: Flávio Ayres Marinho, Doctorate student, Federal University of Tocantins (UFT), Brazil
}

\begin{tabular}{lll}
\hline ARTICLE INFO & & ABSTRACT \\
\cline { 1 - 2 } $\begin{array}{l}\text { Received: } \\
\text { Published: August 25, } 2020\end{array}$ & & $\begin{array}{l}\text { Citation: Flávio Ayres Marinho, Helga Midori Iwamoto, Airton Cardoso Cançado. Social } \\
\text { Management and ICTs: Enhancing Democratic Direct Participation. Biomed J Sci \& Tech }\end{array}$ \\
Res 30(1)-2020. BJSTR. MS.ID.004906.
\end{tabular}

\section{Introduction}

The last decade has been pushing society towards a new direction when considering democracy and deliberation. Some European countries have tried to change their own constitutions by means of democratic deliberation by using information and communication technologies (ICTs) being the case of Iceland, Ireland and Romania the ones previously selected to be studied in this project [1]. Mexico City was also inserted here, for even though not being a country it was the first time that this newly built constitution created by popular participation online was implemented.

\section{Social Management}

Social Management is a social sciences area that since 1990 has a growing number of studies centers, laboratories, post-graduation courses and scientific journals). Further on, it has as a goal to ensure people's expectations are answered by means of increasing popular participation and lastly to achieve emancipation. Participation and debate by means of new technologies can improve democracy by means of widening the public sphere, allowing for citizens' deliberation with the government to take place. Digital democracy, being the use of ICTs to enhance participation and public decisionmaking processes, is a powerful tool capable of engaging groups of people that were previously left aside, establishing this way a new relationship between them and the government. New technology can make democracy more representative and can also improve its own legitimacy by providing this kind of freedom [2].

Moreover, [2], established a research schedule concerning Social Management area, as a science field in progress, to ensure that it developed more theoretical and methodological tools for its consolidation on applied social sciences. As it can be seem in frame 6.2 in this referenced work, one of these goals as to identify possibilities of using ICTs for direct participation on the field of Social Management, and this project can contribute directly to this goal, enhancing it with these new experiences. Further on, it can be said that this doctoral project is inserted in Sociedade, Políticas Públicas e Desenvolvimento Regional research line for it seeks to enhance Social Management theory by analyzing problems and new tools involving society participation. In an effort of synthesis, we can define Social Management as: a dialectical process of the own social organization in the public sphere, founded in the self-interest properly understood and that has as a goal the emancipation of men [3]. All these concepts come together to compose Social Management and can be, following the Negative Dialectics logic [4], redesigned as many times it needs, for here there is not an intention of synthesis, only thesis and antitheses, therefore there is a permanent effort for evolution and change of this theory [2,3].

\section{ICTs and Participation}

ICTs have been growing and being more used each day since 1990s on public institutions for different reasons: For increasing transparency, accountability, efficiency, anti-corruption combat and to promote new forms of public engagement [5-7]. Further on, 
with these 'new' set of tools, it was made possible the creation of a new participatory experience by using electronic means that can be called e-Participation. This participation can take different forms, from forwarding political messages through e-mail and social networks to E-consultations and online petitions [8-10]. Further on, the public sector as well as the organizations have been embracing more social media in order to better engage people, be more transparent and accountable by disseminating useful information and encouraging mass collaboration. Most opportunities for participation, like crowdsourcing and coproduction can be attained within social media, or sometimes even by using intranet to communicate with employees $[11,12]$.

\section{Iceland, Ireland, Romania and Mexico City: A Brief Background}

All of these initiatives, Icelandic, Irish, Romanian and Mexico City reforms took place in the past ten years as a new tendency towards deliberation democracy. In 2012 Iceland produce a constitutional draft, by widely using ICTs which was submitted to a referendum and approximately $50 \%$ of the voters participated, the draft was approved by approximately two thirds in favor of the new constitution. In my dissertation it was sought to analyze this specific case of Iceland, through the perspective of Social Management as to identify if the tools used on the process and how it was conducted could be inserted in this science field. Among the results produced the most significant were the publication of the article: Icelandic Crowd-Sourced Constitution and Social Management: Practice and Theory in Citizens Democratic Participation [13] and of the book Social Management within Icelandic Crowdsourced Constitution [13].

The Irish reform process started also in 2009 after an economic and political crisis. The Parliament Joint Committee on the Constitution proposed that a citizen assembly would be established in order to address the question. In 2011 the "We the Citizens" initiative gathered one hundred randomly selected Irish citizens in order to deliberate, later the government launched the Constitutional Convention and its terms in 2012. Romanian initiative started in 2013 aiming to revise the constitution. A Constitutional forum was also set up in order to ensure engagement and participation. An online platform was created so that Romanian people could participate, 112 topics, 700 comments concerning the constitutional process itself and 11,000 visits emerged, therefore it was considerably successful. The crowd sourcing process involved submissions of proposals from civil society to a parliamentary committee in order to create a basis for their future work.
The Pacto por México following the agreement 91, established that the federal district would become Mexico City and that it would have its own constitution. Therefore, in February 3 of 2017 it was published in the Diario Oficial de la Federación the establishment of the constituent Congress of Mexico City. This congress was composed by 100 citizens which had 60 members elected by people's voting and 40 members appointed by the federal government. Thus, to further enhance this research that begun on my dissertation this project seeks to add more of these experiences to the analysis, this way it is possible to incorporate the results improving Social Management by coming up with new tools and perspectives from different places around the world.

\section{References}

1. Gherghina SA (2014) constitution by the people? The legitimacy of deliberation in the Romanian 2013 reform. ECPR General Conference, University of Glasgow p. 3-6.

2. CANÇADO AC (2013) Gestão social: um debate para a construção do campo. NAU Social 4(6): 191-209.

3. Cançado AC, Pereira JR, Tenório FG (2015a) Gestão social: epistemologia de um paradigma. Curitiba: CRV, 2ª Edição.

4. Adorno T (2003) Negative dialectics. Abingdon, UK: Routledge.

5. Chun S, Luna-Reyes LF, Sandoval-Almazan, Rodrigo (2012) Collaborative e-government. Transforming Government: People, Process and Policy 6(1): 5-12.

6. Carlo Bertot J, Jaeger PT, Grimes JM (2012) Promoting transparency and accountability through ICTs, social media, and collaborative e-government. Transforming Government: People, Process and Policy 6(1): 78-91.

7. Tomkova J (2009) E-consultations: New tools for civic engagement or facades for political correctness. European Journal of ePractice 7: 45-55.

8. Panopoulou E, Tambouris E, Tarabanis K (2009) eParticipation initiatives: How is Europe progressing. European Journal of ePractice 7 : $15-26$.

9. Marinho FA, Cançado AC, Iwamoto HM (2019) Icelandic CrowdSourced Constitution And Social Management: Practice And Theory In Citizens Democratic Participation. Revista Brasileira de Gestão e Desenvolvimento Regional 15(2).

10.Zavattaro SM (2013) Social media in public administration's future: A response to Farazmand. Administration \& Society 45(2): 242-255.

11. Khan GF, Swar B, Lee SK (2014) Social media risks and benefits: A public sector perspective. Social Science Computer Review 32(5): 606-627.

12. Marinho F, Cançado A, Iwamoto H (2019) Social Management within Icelandic Crowdsourced Constitution. Beau-Bassin, Mauritius: LAP.

13. Cançado AC, Pereira JR, Tenório Fg (2015b) Fundamentos Teóricos da Gestão Social. Revista eletrônica do Programa de Mestrado em desenvolvimento Regional da Universidade do Contestado. 
ISSN: 2574-1241

DOI: $10.26717 /$ BJSTR.2020.30.004906

Flávio Ayres Marinho. Biomed J Sci \& Tech Res

(C) Co This work is licensed under Creative

Submission Link: https://biomedres.us/submit-manuscript.php

$\begin{array}{ll}\text { BIOMEDICAL } & \text { Assets of Publishing with us } \\ \text { RESEARCHES } & \text { Global archiving of articles } \\ & \text { - Immediate, unrestricted online access } \\ & \text { - Rigorous Peer Review Process } \\ \end{array}$

